\title{
Soil-vegetation relationships in Mediterranean forests after fire
}

\author{
Víctor Fernández-García* ${ }^{*}$, Elena Marcos, Sara Huerta and Leonor Calvo
}

\begin{abstract}
Background: Wildfires are one of the major environmental concerns in Mediterranean ecosystems. Thus, many studies have addressed wildfire impacts on soil and vegetation in Mediterranean forests, but the linkages between these ecosystem compartments after fire are not well understood. The aim of this work is to analyze soil-vegetation relationships in Mediterranean burned forests as well as the consistency of these relationships among forests with different environmental conditions, at different times after fire, and among vegetation with different functional traits.

Results: Our results indicate that study site conditions play an important role in mediating soil-vegetation relationships. Likewise, we found that the nature of soil-vegetation relationships may vary over time as fire effects are less dominant in both ecosystem compartments. Despite this, we detected several common soil-vegetation relationships among study sites and times after fire. For instance, our results revealed that available $\mathrm{P}$ content and stoichiometry (C:P and N:P) were closely linked to vegetation growth, and particularly to the growth of trees. We found that enzymatic activities and microbial biomass were inversely related to vegetation growth rates, whereas the specific activities of soil enzymes were higher in the areas with more vegetation height and cover. Likewise, our results suggest that resprouters may influence soil properties more than seeders, the growth of seeders being more dependent on soil status.

Conclusions: We provide pioneer insights into how vegetation is influenced by soil, and vice-versa, in Mediterranean burned areas. Our results reflect variability in soil-vegetation relationships among study sites and time after fire, but consistent patterns between soil properties and vegetation were also detected. Our research is highly relevant to advance in forest science and could be useful to achieve efficient post-fire management.
\end{abstract}

Keywords: Wildfires, Soil nutrients, Enzymatic activities, Microbial biomass, Growth forms, Regenerative strategies

\section{Background}

Mediterranean regions are characterized by a seasonal climate, with mild winters that promote fuel accumulation and hot dry summers, facilitating the occurrence of wildfire. Therefore, wildfires have shaped ecological processes in Mediterranean forest ecosystems for millennia, providing suitable study systems for the fire ecology discipline (Keeley et al. 2011; Moreira et al. 2020). Moreover, recent changes in fire

\footnotetext{
* Correspondence: vferg@unileon.es

Area of Ecology, Department of Biodiversity and Environmental

Management, Faculty of Biological and Environmental Sciences, Universidad de León, 24071 León, Spain
}

\section{Springer Open}

(c) The Author(s). 2021 Open Access This article is licensed under a Creative Commons Attribution 4.0 International License, which permits use, sharing, adaptation, distribution and reproduction in any medium or format, as long as you give appropriate credit to the original author(s) and the source, provide a link to the Creative Commons licence, and indicate if changes were made. The images or other third party material in this article are included in the article's Creative Commons licence, unless indicated otherwise in a credit line to the material. If material is not included in the article's Creative Commons licence and your intended use is not permitted by statutory regulation or exceeds the permitted use, you will need to obtain permission directly from the copyright holder. To view a copy of this licence, visit http://creativecommons.org/licenses/by/4.0/.

regimes aggravated by human activity intensification and climate change (Dupuy et al. 2020; Moreira et al. 2020) are fostering the interest of the scientific community in better understanding ecological processes in Mediterranean forests after fire (Fernández García et al. 2020; Sáenz de Miera et al. 2020).

Soils are an essential resource that may undergo significant changes when exposed to fire in terms of physical, chemical and biochemical properties (Certini 2005; Boerner and Brinkman 2006; Fernández-García et al. 2019a; Verma et al. 2019). Changes in soils caused by fire may be more or less persistent depending on several factors (e.g. fire frequency, fire intensity and severity, 
type of soil and post-fire environmental conditions) (Cerda and Robichaud 2009; Fernández-García et al. 2019b), but in general, recently burned soils are more prone to erosion than unburned soils, as they tend to be more hydrophobic, less structured and less protected by an organic layer (Pereira et al. 2017). Additionally, soils show decreases in organic matter after fire, and at the same time tend to be richer in available forms of nitrogen and phosphorus (Certini 2005; Cerda and Robichaud 2009; Caon et al. 2014). Likewise, fire modifies soil biochemical properties, in general, decreasing microbial biomass and soil enzymatic activity for several years, which brings about a slowdown of soil biochemical reactions (Fernández-García et al. 2019a, 2019b; FernándezGarcía et al. 2020). All these properties and processes are closely related to soil quality, and they determine vegetation composition and growth, but little is known about the interaction of both ecosystem compartments in post-fire environments (Moya et al. 2018; Quigley et al. 2020).

In Mediterranean ecosystems, the predominance of crown fires leads to large reductions in the amount of vegetation for several years (Keeley et al. 2011). However, Mediterranean vegetation is highly resilient to fire (Calvo et al. 2002; De Luis et al. 2006), to the point that post-fire regeneration has been described as an autosuccessional process that starts during the weeks following fire (Trabaud 1991). Consequently, soil-vegetation interactions continue in post-fire environments under extraordinary conditions that influence growth rates and species composition. In this sense, growth forms and regenerative strategies have been considered key traits in determining vegetation fitness to fire and their resourceuse capacity in post-fire environments (Ojeda et al. 2005; Blair et al. 2016; Fernández García et al. 2020). Previous work has indicated that herbaceous species can colonize burned areas easier than other growth forms (Capitanio and Carcaillet 2008), and can take advantage of the nutrients provided by ash because of their superficial roots and rapid growth (Calvo et al. 2003). Focusing on woody species, most shrubs and trees in Mediterranean ecosystems can be grouped according to their regenerative strategies after fire as (i) obligate resprouters, which are those species that regenerate after fire only from buds, (ii) obligate seeders, which only regenerate from seeds, and (iii) facultatives (also known as facultative seeders or facultative resprouters), which can regenerate by both resprouting and seeding (Calvo et al. 2003; Arnan et al. 2007; Pausas and Keeley 2014). With respect to this matter, resprouting allows plants to rapidly regenerate from the surviving biomass, being advantageous over seeding in competitive environments (Pausas and Keeley 2014). On the contrary, seeding is advantageous when seedling success and adult mortality are high, which occurs in scarcely competitive environments and in ecosystems affected by intense wildfires (Pausas and Keeley 2014).

Although the effects of fire on soil and vegetation have captured most of the attention in forest fire research (e.g. Calvo et al. 2003; Certini 2005; Fernández-García et al. 2019a; Fernández García et al. 2020) it is crucial to comprehend soil-vegetation relationships to understand ecosystem functioning and accomplish efficient ecosystem management (Aponte et al. 2011; Moya et al. 2018; Quigley et al. 2020; Stevens et al. 2020). Currently, it is well known that in non-disturbed environments there is a strong feedback dynamic between soil and vegetation, soil affecting vegetation growth and composition, and in turn, vegetation determining soil properties by modifying organic matter fluxes, nutrient returns and soil environmental conditions (Aponte et al. 2010, 2011; Sardans and Peñuelas 2013). Specifically, some studies have addressed soil-vegetation relationships after fire in Mediterranean ecosystems. Among them, Keesstra et al. (2017) suggested that vegetation recovery can increase soil water repellency in Pinus halepensis Mill. forests in Israel; Moya et al. (2018) found that vegetation regeneration determined soil chemical properties, including $\mathrm{pH}$, electrical conductivity and several soil nutrients in $P$. halepensis forests in the southeastern Iberian Peninsula; and López-Poma and Bautista (2014) and Mayor et al. (2016) revealed positive relationships between vegetation cover and soil enzyme activities in fire-prone shrublands in the eastern Iberian Peninsula, the correlation being stronger in the case of obligate resprouter shrubs than obligate seeders. However, previous research was restricted to a single ecosystem type and region or to a single post-fire date, requiring a broader analysis to determine whether there are consistent patterns in soilvegetation relationships in Mediterranean forests after fire.

The objective of the present work is to study soilvegetation relationships in Mediterranean forest ecosystems after fire. Specifically, we aim to analyze the relationship between soil chemical and biochemical variables (total organic $\mathrm{C}$, total $\mathrm{N}$, available $\mathrm{P}, \mathrm{C}: \mathrm{N}, \mathrm{C}: \mathrm{P}$ and $\mathrm{N}: \mathrm{P}$ ratios, $\beta$-glucosidase, urease, phosphatase, microbial biomass $C$, and the ratios of $\beta$-glucosidase, urease and phosphatase to microbial biomass $C$ ) and vegetation variables (height and cover differentiating growth forms and regenerative strategies) (i) in contrasting Mediterranean environmental conditions, (ii) at different times after wildfire (1-2 and 3-4 years), (iii) in terms of absolute values and annual percentage change. We hypothesize that there are consistent relationships between soil and vegetation in different environmental conditions, in terms of both absolute values and annual changes. We expect soil-vegetation relationships to be 
stronger over the short term after fire (3-4 years) than over the very short term after fire (1-2 years), because over the very short-term soil-vegetation feedbacks could be dissembled by the direct fire impact. In view of previous work (López-Poma and Bautista 2014; Mayor et al. 2016), we anticipate different soil-vegetation relationships depending on vegetation functional traits. For instance, considering faster growth of resprouter species and higher resource-use, we expect obligate resprouters to cause greater annual changes in soils than obligate seeders. On the contrary, the annual growth of obligate seeders would be more dependent on soil status, because they cannot take advantage of endogenous resources to fund regrowth.

\section{Methods}

\section{Study sites}

We selected four study sites (Cabrera, Gátova, Teleno and Cortes), representing Mediterranean ecosystems with contrasting climatic conditions and soil types (Fig. 1; Table 1). The four study sites were affected by wildfires that consumed most of the tree canopy cover, the dNBR burn severity index averaging values above 400 (Table 1; Table A1), which indicates moderate-high and high severities (Key and Benson 2006). Likewise, the four study sites have congruent fire histories, with a mean fire frequency of about 0.16 fires per decade (Table 1; Table A1).

The Cabrera and Teleno study sites are located in the north-western Iberian Peninsula (Spain) (Fig. 1). Both sites are characterized by a Mediterranean climate with dry temperate summers (AEMET-IM 2011), averaging 2 months of summer drought. Soils in this region were developed over siliceous lithologies (quartzite, sandstone, slate and conglomerates; GEODE 2020) and are characterized by a sandy loam or sandy clay loam texture, and low nutrient content (Table 1). In August 2017, a wildfire in the Cabrera study site burned $99 \mathrm{~km}^{2}$ of Quercus pyrenaica Willd. forests, Erica australis L. heathlands and Genista hystrix Lange shrublands. In the Teleno study site, a wildfire in August 2012 burned $119 \mathrm{~km}^{2}$, mainly dominated by Pinus pinaster Ait. ecosystems with understory dominated by $E$. australis, Halimium lasianthum (Lam.) Spach, and Pterospartum tridentatum (L.) Willk.

The Gátova and Cortes study sites are located in the eastern Iberian Peninsula (Spain) (Fig. 1). Both are characterized by typical Mediterranean conditions, with warm dry summers (AEMET-IM 2011) resulting in 4 months of summer drought. Soils in both study sites were originated from calcareous lithologies (limestone, dolomite, sandstone, marl and gypsum; GEODE 2020) and have a loamy sand or sandy loam texture, and higher nutrient contents than the north-western study sites (Table 1). In Gátova, a wildfire that started in June 2017 burned $14 \mathrm{~km}^{2}$, mostly Pinus halepensis Mill. ecosystems. In Cortes, a wildfire initiated in June 2012 affected $297 \mathrm{~km}^{2}$, large extents being dominated by $P$. halepensis forests.

\section{Field sampling}

We randomly distributed 100 field plots of $30 \mathrm{~m} \times 30 \mathrm{~m}$ in the four study sites (22 in Cabrera, 15 in Gátova, 33

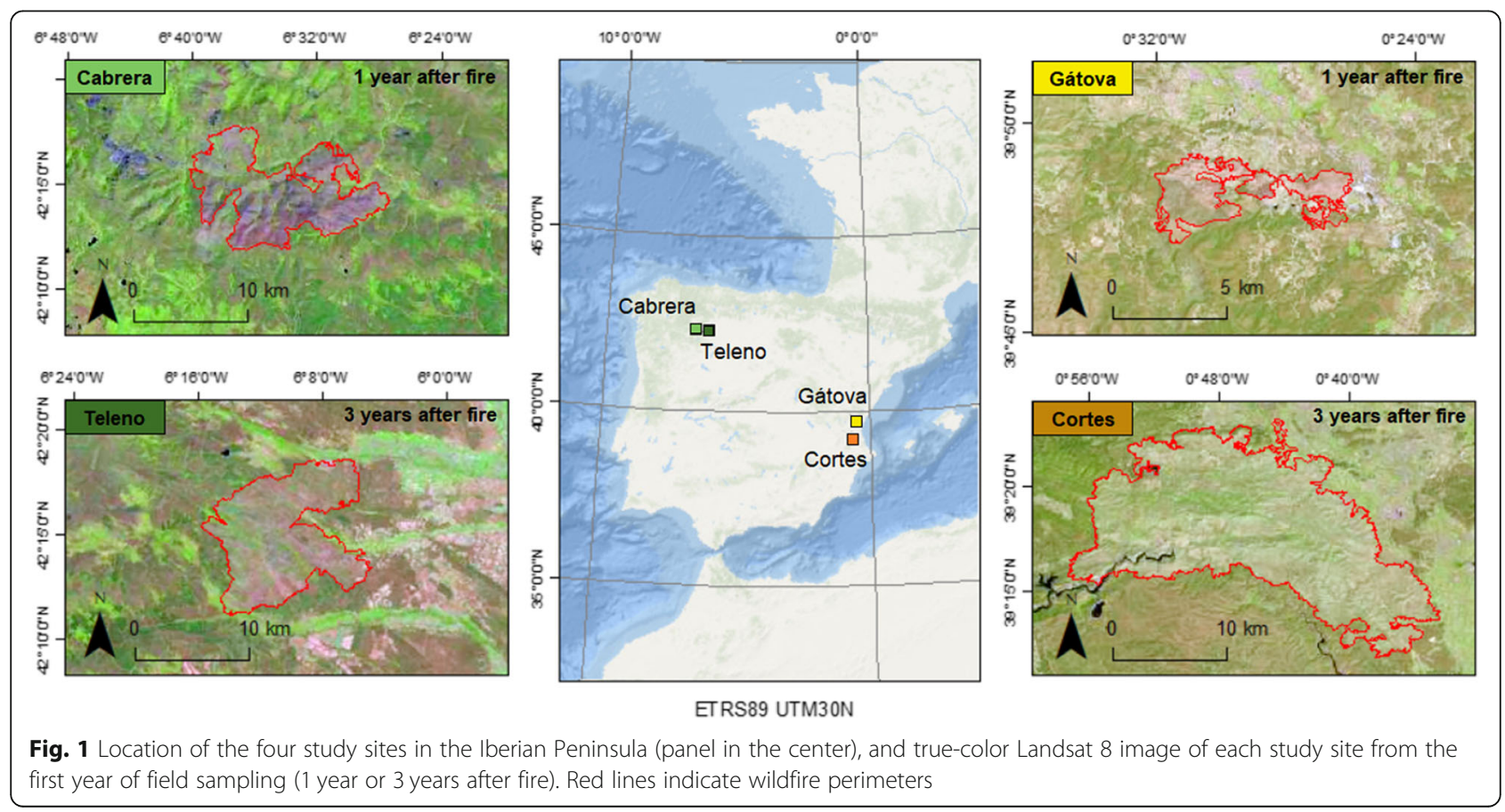


Table 1 Characteristics of the study sites

\begin{tabular}{|c|c|c|c|c|}
\hline & Cabrera & Gátova & Teleno & Cortes \\
\hline Fire alarm date & August 21st, 2017 & June 28th, 2017 & August 19th, 2012 & June 28th, 2012 \\
\hline Wildfire size $\left(\mathrm{km}^{2}\right)$ & 99.39 & 14.14 & 118.91 & 297.52 \\
\hline a Burn severity (dNBR) & 424 & 406 & 695 & 588 \\
\hline${ }^{b}$ Fire frequency (fires decade ${ }^{-1}$ ) & 0.16 & 0.14 & 0.16 & 0.17 \\
\hline Sampling date (year) & $\begin{array}{l}\text { 2018, } 2019 \\
\text { (1-2 after fire) }\end{array}$ & $\begin{array}{l}\text { 2018, } 2019 \\
\text { (1-2 after fire) }\end{array}$ & $\begin{array}{l}\text { 2015, } 2016 \\
\text { (3-4 after fire) }\end{array}$ & $\begin{array}{l}\text { 2015, } 2016 \\
\text { (3-4 after fire) }\end{array}$ \\
\hline Elevation (m) & $838-1960$ & 290-815 & $836-1493$ & $120-942$ \\
\hline c Precipitation (mm) & $650-1000$ & $350-600$ & $600-800$ & $400-600$ \\
\hline${ }^{\mathrm{C}}$ Temperature $\left({ }^{\circ} \mathrm{C}\right)$ & $5-11$ & $14-16$ & $8-11$ & $13-17$ \\
\hline d Soil pH & 5.39 & 8.33 & 4.63 & 8.14 \\
\hline${ }^{\mathrm{e}}$ Total organic $\mathrm{C}\left(\mathrm{mg} \mathrm{C} \cdot \mathrm{g}^{-1}\right.$ soil) & 51.89 & 66.14 & 52.24 & 36.74 \\
\hline${ }^{\mathrm{f}}$ Total N (mg N.g ${ }^{-1}$ soil) & 4.04 & 2.87 & 2.07 & 2.87 \\
\hline${ }^{g}$ Available $\mathrm{P}\left(\mu \mathrm{g} \mathrm{P} \cdot \mathrm{g}^{-1}\right.$ soil) & 17.89 & 25.74 & 7.14 & 10.51 \\
\hline Vegetation cover (\%) & 42.88 & 24.07 & 52.79 & 48.40 \\
\hline
\end{tabular}

${ }^{a}$ Burn severity calculated through the dNBR spectral index using Landsat imagery (see Fernández-García et al. 2018). ${ }^{\mathrm{b}}$ The period 1990-2020 (30 years) was used for the calculation of fire frequency in the study sites. ${ }^{c}$ Mean annual precipitation and temperature obtained from Ninyerola et al. (2005). ${ }^{\mathrm{d}} \mathrm{pH}$ determined by a suspension of soil:deionized water (1:2.5, w/v). ${ }^{e}$ Total organic $\mathrm{C}$ calculated with the dry combustion method (Dumas 1831). ${ }^{\mathrm{f}}$ Total $\mathrm{N}$ calculated with the Kjeldahl method (Bremner and Mulvaney 1982). ${ }^{\mathrm{g}}$ Available P calculated with the Olsen et al. (1954) method

in Teleno and 30 in Cortes). In each $30 \mathrm{~m} \times 30 \mathrm{~m}$ plot, we systematically established 2 plots of $2 \mathrm{~m} \times 2 \mathrm{~m}$ (Fig. 2), which were fixed in the field and georeferenced with high precision GPS (RMSE $X, Y<0.5 \mathrm{~m}$ ) for monitoring in different years. Specifically, we sampled soil and vegetation in May-June of two subsequent years in the four study sites: 1 and 2 years after wildfire in Cabrera and

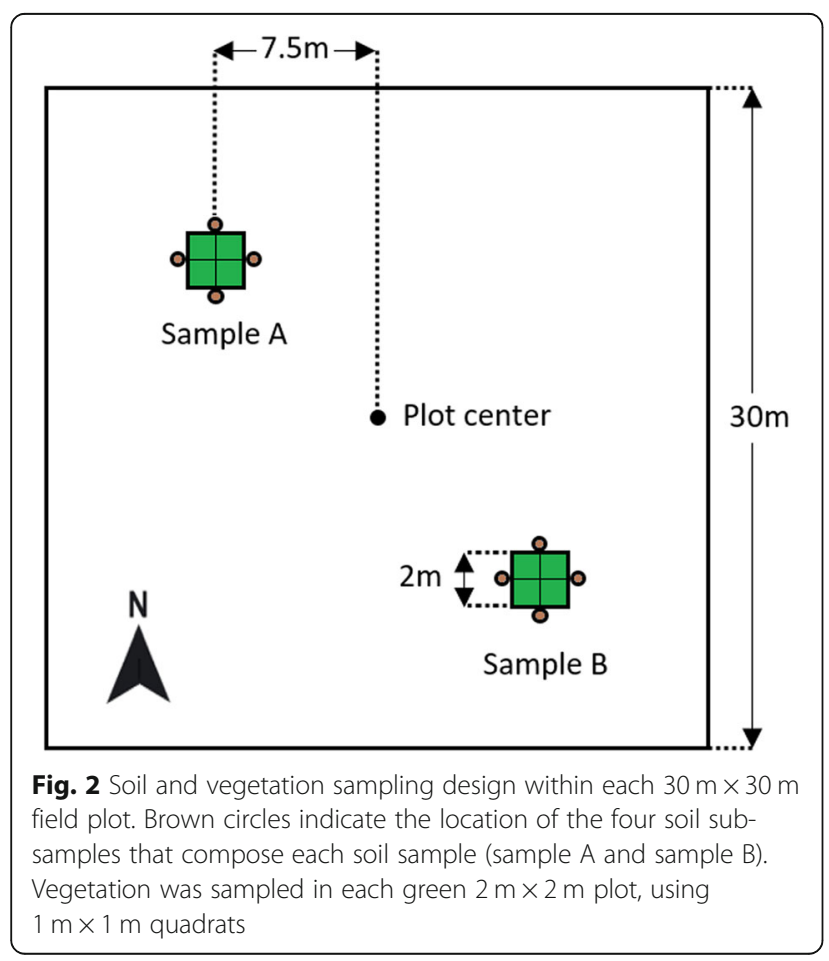

Gátova (very short-term), and 3 and 4 years after wildfire in Teleno and Cortes (short-term).

In each $2 \mathrm{~m} \times 2 \mathrm{~m}$ plot we collected a sample of mineral soil, composed by four subsamples taken from a depth of $3 \mathrm{~cm}$. Soil subsamples were taken at the four cardinal points of each $2 \mathrm{~m} \times 2 \mathrm{~m}$ plot (see Fig. 2) to obtain a representative sample of the soil. These samples were air dried, sieved at $2 \mathrm{~mm}$ and stored until laboratory analysis, which was performed during the 3 months after sampling. Likewise, vegetation sampling was carried out in each $2 \mathrm{~m} \times 2 \mathrm{~m}$ plot using 4 observational units of $1 \mathrm{~m} \times 1 \mathrm{~m}$ (Fig. 2), in which we measured the following vegetation variables: (i) maximum vegetation height, (ii) total percentage cover of vegetation, (iii) percentage cover of vegetation differentiated by growth forms (trees, shrubs and herbs), and (iv) percentage cover of vegetation differentiated by regenerative strategies (obligate resprouters, hereafter resprouters; obligate seeders, hereafter seeders and facultative seeders or facultative resprouters, hereafter facultatives) (See species classification in Table A2 - supplementary material).

\section{Soil analysis and calculations}

In this work, we studied (i) chemical variables of the soil: total organic $\mathrm{C}$ (TOC), total $\mathrm{N}(\mathrm{TN})$, available $\mathrm{P}(\mathrm{AP})$, C: $\mathrm{N}$ ratio, C:P ratio and N:P ratio; and (ii) biochemical variables of the soil: $\beta$-glucosidase, urease and phosphatase, microbial biomass $C(\mathrm{MBC})$, and the ratios of $\beta$ glucosidase, urease and phosphatase to $\mathrm{MBC}$. 
In the Cabrera and Gátova study sites, TOC was determined following the combustion method (Dumas 1831), using a EuroVector EA3000 elemental analyzer (Eurovector SpA, Italy). In Teleno and Cortes, we determined oxidizable organic $\mathrm{C}$ by Walkley-Black dichromate oxidation (Nelson and Sommers 1982) after grinding the soils to $<0.15 \mathrm{~mm}$ particle size, and oxidizable organic $\mathrm{C}$ was converted to TOC using a correction factor of 1.32 (Walkley and Black 1934). TN was analyzed by the Kjeldahl procedure (Bremner and Mulvaney 1982) with a DK 20 digestion unit (VELP Scientifica, Italy) and AP was determined following the Olsen et al. (1954) method, at $882 \mathrm{~nm}$ wavelength on a UV Mini $1240 \mathrm{spec}-$ trophotometer (Shimadzu Corporation, Japan).

$\beta$-glucosidase (EC 3.2.1.21; $\beta$-D-glucoside glucohydrolase) and acid-phosphatase (phosphatase: EC 3.1.3.2; phosphatemonoester phosphohydrolase) activities were determined following the procedure described by Tabatabai (1994), and urease (urease: EC 3.5.1.5; urea amidohydrolase) activity according to Kandeler and Gerber (1988). The analytical procedure for the three enzymes consists of (i) adding excess of the correspondent enzyme substrate to soil samples ( $\mathrm{p}$ nitrophenyl- $\beta$-D-glucopyranoside for $\beta$-glucosidase, $p$ nitrophenyl-phosphate for phosphatase and urea for urease), (ii) incubating soil samples with the enzyme substrate in shaking at $37^{\circ} \mathrm{C}$, and (iii) determining colorimetrically the enzyme products released in the incubation period [pnitrophenol ( $\mathrm{pNP}$ ) for $\beta$-glucosidase and phosphatase, and $\mathrm{NH}_{4}{ }^{+}$for urease]. pNP was measured at 400-nm wavelength, and $\mathrm{NH}_{4}{ }^{+}$at $690 \mathrm{~nm}$ with a UV-1700 PharmaSpec spectrophotometer (Shimadzu Corporation, Japan).

MBC was determined by the chloroform fumigationextraction method (Vance et al. 1987). Thus, we calculated the difference $\left(E_{C}\right)$ in organic $C$, determined by WalkleyBlack dichromate oxidation, between chloroform fumigated $\left(\mathrm{CHCl}_{3}, 24 \mathrm{~h}\right)$ and non-fumigated soil samples. Then, we calculated microbial biomass $\mathrm{C}$ using the following the formula: $\mathrm{MBC}=\mathrm{E}_{\mathrm{C}} / \mathrm{k}_{\mathrm{EC}}$, where $\mathrm{k}_{\mathrm{EC}}$ is an extraction efficiency coefficient of 0.38 (Vance et al. 1987; Joergensen 1996).

Additionally, we calculated soil ratios reflecting the soil nutrient stoichiometry (C:N, C:P and $\mathrm{N}: \mathrm{P}$ ) and physiological capacity of soil microorganisms (specific activity of $\beta$-glucosidase, urease and phosphatase). We calculated the $\mathrm{C}: \mathrm{N}$ ratio as micrograms of TOC to micrograms of TN; the C:P ratio as micrograms of TOC to micrograms of $\mathrm{AP}$, and the $\mathrm{N}: \mathrm{P}$ as micrograms of TN to micrograms of AP. Likewise, the specific activity of soil enzymes was expressed as micrograms of product released ( $\mathrm{pNP}$ for $\beta$-glucosidase and phosphatase, and $\mathrm{NH}_{4}{ }^{+}$for urease) per microgram of MBC.

\section{Data analysis}

For each sampling date, we calculated the mean values of soil variables (chemical and biochemical) and vegetation variables (vegetation height per $\mathrm{m}^{2}$, total percentage cover, percentage cover by growth forms and percentage cover by regenerative strategies) in each 30 $\mathrm{m} \times 30 \mathrm{~m}$ plot by averaging the data obtained in their corresponding $2 \mathrm{~m} \times 2 \mathrm{~m}$ plots. Additionally, using the values of the two sampling dates, we calculated the annual percentage change of the studied soil and vegetation variables.

An exploratory analysis of the data was carried out to select the most appropriate method to study the soilvegetation relationships. We performed a Shapiro-Wilk normality test and scatterplots that revealed the nonnormality of many studied variables and non-linear relationships between them. Thus, a one-sample Wilcoxon test was performed to check whether annual changes in soil and vegetation variables were significantly different to zero $(p<0.05)$. Likewise, soil-vegetation relationships were studied through Spearman correlation tests (rhovalue and significance). Specifically, in each study site we studied the correlations between: (i) the mean values of soil variables and the mean values of vegetation variables, (ii) the annual percentage change in vegetation variables and the initial values of soil variables (values of soil variables the first year of sampling), (iii) the annual percentage change in soil variables and the initial values of vegetation variables.

All statistical analyses were performed with $\mathrm{R}$ ( $\mathrm{R}$ Core Team 2020), using the Hmisc package (Harrell 2020).

\section{Results}

\section{Characterization of soil and vegetation status and dynamics}

Soil analysis revealed that recently burned sites (1-2 years) had the highest AP values, $\mathrm{C}: \mathrm{P}$ and $\mathrm{N}: \mathrm{P}$ ratios and the lowest $\beta$-glucosidase activity (Table A3 - supplementary material). Urease and phosphatase activities were, in general, higher in the north-western sites (Cabrera and Teleno, which are colder, wetter and have siliceous soils), regardless of the time after fire. The rest of soil properties showed large differences among study sites (Table A3 - supplementary material). Results for the annual percentage change (Fig. 3) showed generalized decreases in TOC, AP and C:N in time, while C:P and $\mathrm{N}: \mathrm{P}$ ratios tended to increase (both, over the very short and short term). Soil enzymatic activities ( $\beta$-glucosidase, urease and phosphatase) and MBC showed annual increases in all study sites, except for phosphatase in Teleno. The specific activity of enzymes (ratios of enzyme activity to $\mathrm{MBC}$ ) showed variable behaviour among sites.

In relation to vegetation, we found greater height and total cover in the sites studied over the short term after fire (3-4 years) than in the recently burned ones (1-2 years) (Table A4 - supplementary material). Results also 


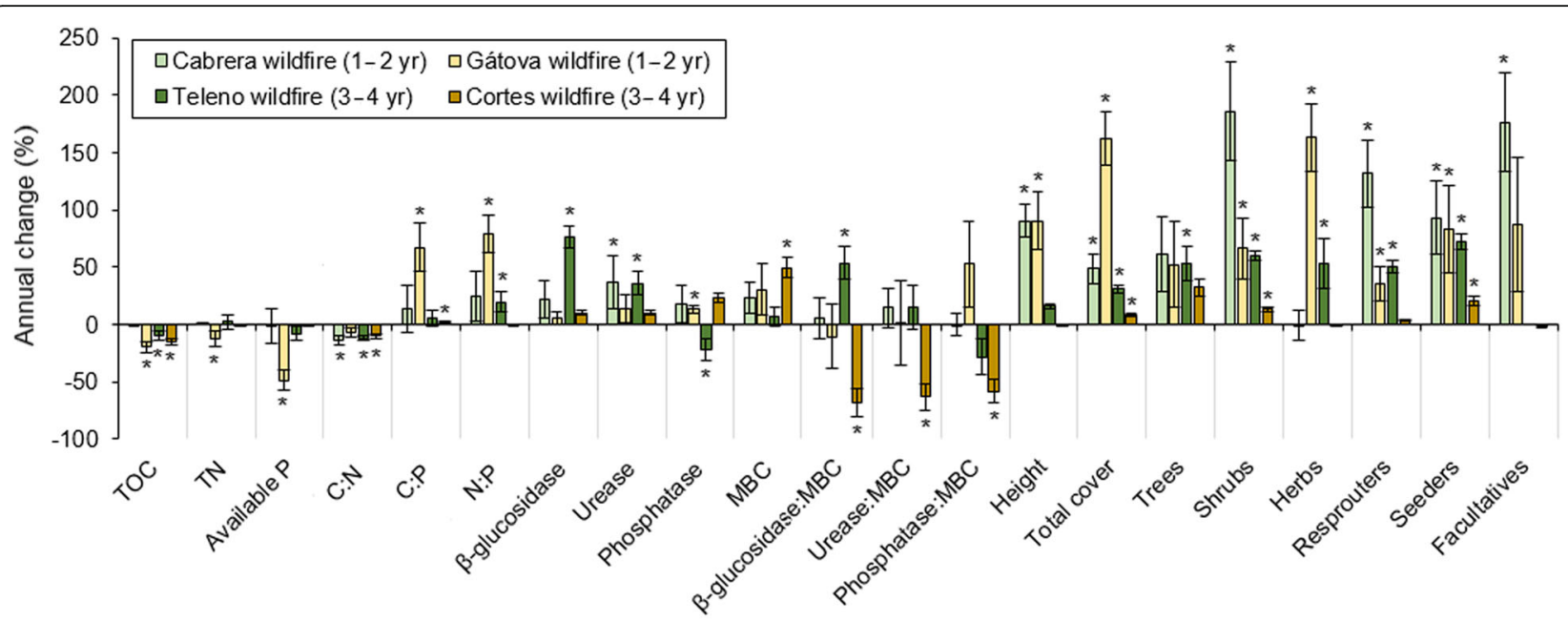

Fig. 3 Annual percentage change of soil and vegetation variables in the four study sites. * above bars indicates significant annual change $(p<0.05)$

indicate that trees were relatively abundant in Cabrera and Gátova, whereas shrubs clearly dominated Teleno and Cortes. Among woody species, resprouters dominated the north-western study sites whereas seeders dominated the eastern ones (Gátova and Cortes, which are warmer, drier and calcareous). Analyzing the annual changes in vegetation (Fig. 3), we found generalized increases in height and cover, which were more pronounced in the recently burned sites. Facultative species were not found in the Teleno plots.

\section{Soil-vegetation relationships in terms of absolute values}

In general, the correlations between soil and vegetation absolute values showed variable results, depending on the time after fire and environmental conditions (study sites), as well as depending on growth forms and regenerative strategies (Fig. 4). At the community level, we found that vegetation height and cover tended to be positively related to the specific activity of soil enzymes (enzyme activity to $\mathrm{MBC}$ ) in most cases, four of 24 relationships being significant.

Focusing on growth forms, tree cover was higher in areas with elevated AP content and stoichiometry (low $\mathrm{C}: \mathrm{P}$ and $\mathrm{N}: \mathrm{P})$ over the short term. In addition, trees were positively related to most soil biochemical variables over the very short term ( 5 of 14 relationships being significant), but inversely related to them over the short term (5 of 14 relationships being significant). In the northwestern sites (Cabrera and Teleno), shrubs had higher cover in areas with lower AP, in terms of both concentration and stoichiometry (C:P and $\mathrm{N}: \mathrm{P})$, whereas herbs showed opposite patterns over the very short and short term.

Differentiating regenerative strategies, results indicated that resprouters cover was positively related to TN, C:P, and N:P in most study sites (3 of 6 relationships being significant), and to soil enzymatic activities over the short term (3 of 6 relationships being significant). Nevertheless, seeders did not show consistent patterns among study sites, whereas facultatives were positively related to AP, and inversely related to C:N and C:P (3 of 9 relationships being significant).

\section{Relationships between soil absolute values and annual change in vegetation}

Results showed that roughly, vegetation growth (height and total cover) tended to be positively related to AP content and stoichiometry (low C:P and $\mathrm{N}: \mathrm{P}$ ratios) and inversely to enzymatic activities and $\mathrm{MBC}$, although most correlations were not significant and there were differences among study sites (Fig. 5). Moreover, increases in height and cover tended to be inversely related to the $\mathrm{N}: \mathrm{P}$ ratio, enzymatic activities and $\mathrm{MBC}$, three of the correlations being significant.

Differentiating growth forms, the growth of trees and shrubs (annual change in cover) showed stronger correlations than herbaceous vegetation with soil variables. Tree growth was positively related to AP content and stoichiometry (C:P, N:P) (3 of 12 relationships being significant), and inversely related to phosphatase activity and MBC (1 of 8 relationships being significant). On the contrary, the growth of shrubs showed contrasting patterns depending on the time after fire.

In relation to regenerative strategies, we found that the growth of seeders and facultatives (annual change in cover) exhibited stronger correlations than that of resprouters with soil variables. Roughly, the growth of seeders was greater in areas with high TOC, TN and AP, and with low C:P and N:P ratios. 


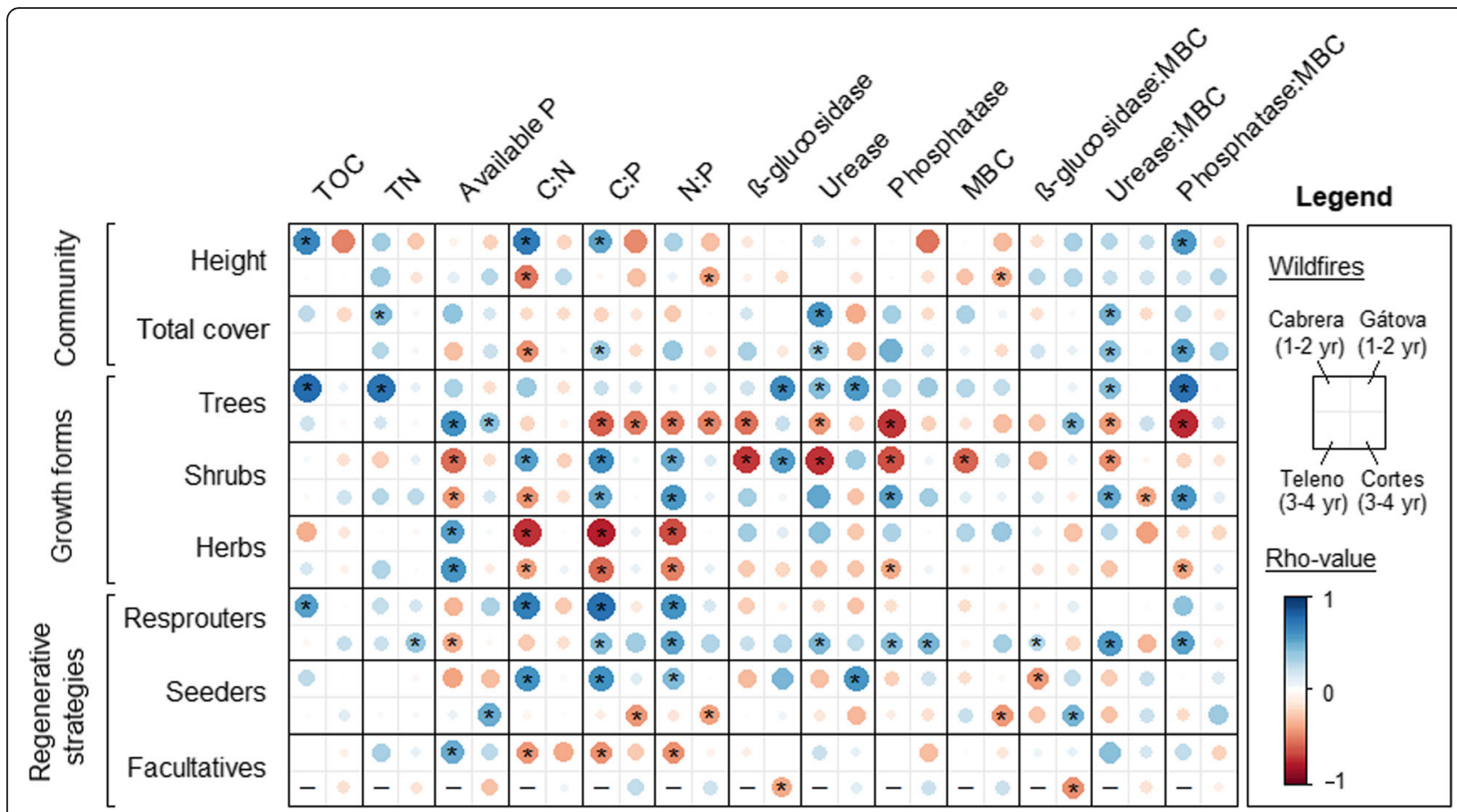

Fig. 4 Relationships between soil and vegetation variables in terms of mean absolute values (average values from 1 and 2 years after fire in Cabrera and Gátova - in the upper part of each square, and from 3 and 4 years after fire in Teleno and Cortes -in the bottom of each square). Height was measured in $\mathrm{cm}$ as the mean maximum height per $\mathrm{m}^{2}$, total cover and the cover by growth forms and regenerative strategies were calculated as the mean percentage cover. Circle sizes are proportional to the absolute value of Spearman's correlation coefficient (Rho-value). ${ }^{*}$ indicates significant correlation $(p<0.05)$. A hyphen indicates that data are not available

\section{Relationships between vegetation absolute values and annual changes in soil}

Results showed that generally, the relationship between annual changes in soil and vegetation variables varied among study sites (Fig. 6). However, at community level we found that $\mathrm{C}: \mathrm{P} ; \mathrm{N}: \mathrm{P}$ ratios increased in the areas with more vegetation, mainly over the very short term after fire (3 of 8 relationships being significant).

Differentiating growth forms, results indicate that increases in C:P and N:P ratios over the very short term were larger in areas with high cover of trees and shrubs. Differentiating regenerative strategies, we found the cover resprouters to be more related to changes in soil properties than seeders (i.e.: TOC, TN and AP tended to decrease with resprouter cover). Results also revealed that increases in specific enzyme activities over the very short term were positively related with tree cover ( 2 of 6 relationships being significant).

\section{Discussion}

\section{Soil and vegetation dynamics in Mediterranean forests} after fire

Our study shows the post-fire dynamics of soil and vegetation in Mediterranean forests ecosystems affected by crown fires, 1 to 2 and 3 to 4 years after fire. Specifically, we found that soil organic C, AP and $\mathrm{C}: \mathrm{N}$ ratio undergo annual decreases the years following fire, whereas the enzymatic activities, MBC and vegetation cover and height exhibit significant increases. Many studies have reported that combustion decreases the organic $\mathrm{C}$ concentration and $\mathrm{C}: \mathrm{N}$ ratio in forests from different Mediterranean-type climate regions such as the conifer and oak ecosystems of the Mediterranean Basin (Kutiel and Naveh 1987; Pereira et al. 2012; Vega et al. 2013) and California (Goforth et al. 2005) as well as in Eucalyptus and Acacia ecosystems of Australia (Bui and Henderson 2013). Moreover, we found decreases in both variables in the post-fire environment, which can be a consequence of increases in mineralization rates (Alcañiz et al. 2016). Likewise, fire increases AP concentration, particularly at moderate and high severities (Vega et al. 2013), but the following years may experience decreases, as it is immobilized, adsorbed onto mineral surfaces, leached, or assimilated by plants (Hinojosa et al. 2016; Fernández-García et al. 2019c). This dynamic is common in all types of forests (Certini 2005) and thus it is expected for the different Mediterranean forests across the globe (Kutiel and Naveh 1987; Caon et al. 2014). The enzymatic activities and $\mathrm{MBC}$ are intensely slowed down with burn severity in Mediterranean forests (Miesel et al. 2011; Vega et al. 


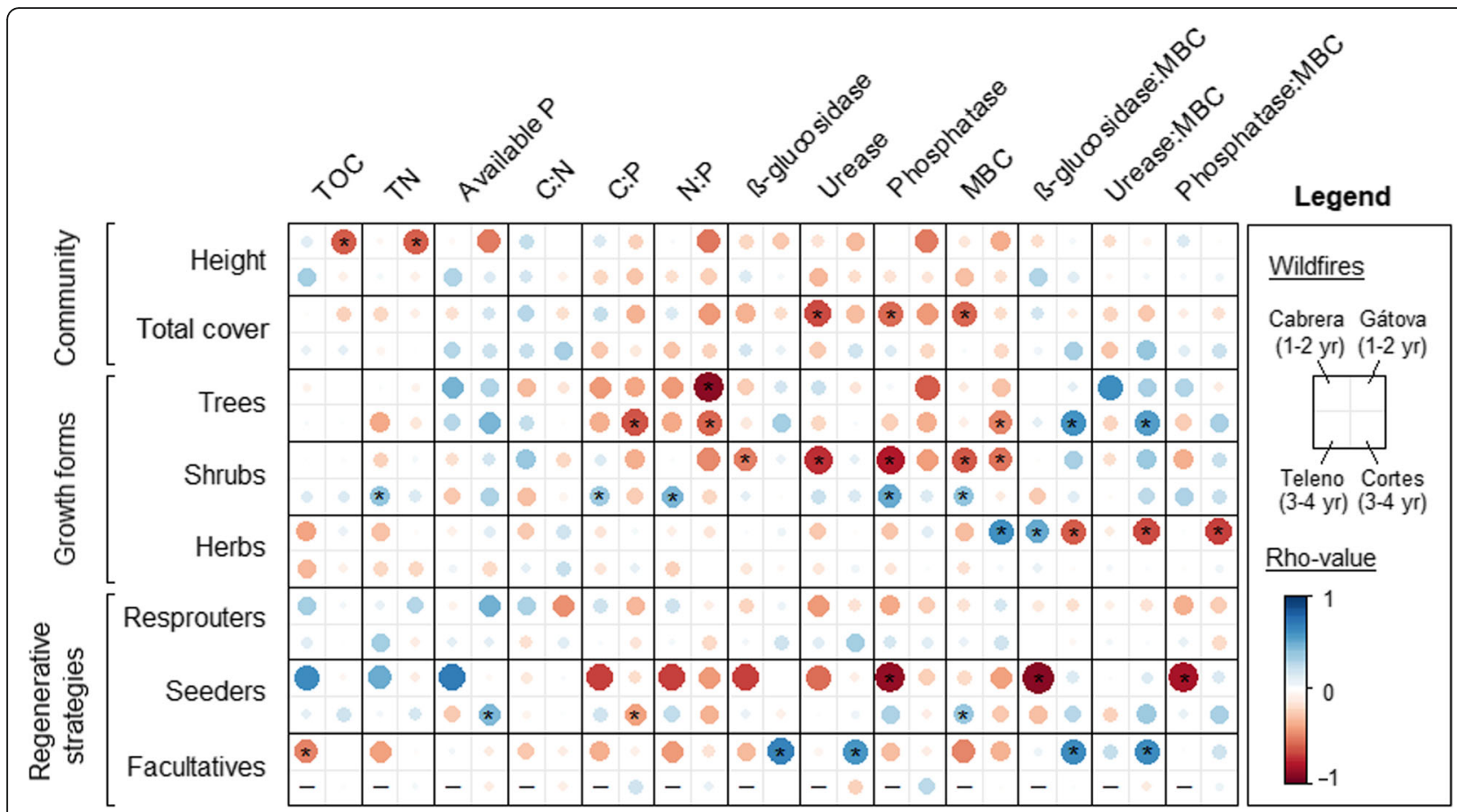

Fig. 5 Relationships between soil absolute values the first sampling year (1 year after fire in Cabrera and Gátova; 3 years after fire in Teleno and Cortes), and the annual percentage change in vegetation variables between the 2 years of field sampling ( 1 and 2 years after fire in Cabrera and Gátova, 3 and 4 years after fire in Teleno and Cortes). Height was measured in $\mathrm{cm}$ as the mean maximum height per $\mathrm{m}^{2}$, total cover and the cover by growth forms and regenerative strategies were calculated as the mean percentage cover. Circle sizes are proportional to the absolute value of Spearman's correlation coefficient (Rho-value). ${ }^{*}$ indicates significant correlation $(p<0.05)$. A hyphen indicates that data are not available

2013; Pourreza et al. 2014; Fernández-García et al. 2019a), with annual increases thereafter. Both variables are closely related, as soil microorganisms are the main source of soil enzymes (Tabatabai 1994; Hinojosa et al. 2016), and their increase could be attributed to the amelioration of soil microclimatic conditions and the recovery of vegetation (FernándezGarcía et al. 2020). This assumption is supported by our results, as we found significant increases in vegetation height and cover, which varied with functional traits in the different study sites. In relation to growth forms, shrubs showed larger increases than trees the first years after fire (1-2 years), which has been attributed to their high resilience and higher productivity in the early successional stages (Montès et al. 2004). Analyzing the regenerative strategies, we found resprouting dominated over seeding in the northwestern sites (siliceous and cooler), and the opposite pattern in south-eastern sites (calcareous and drier). According to previous work in Mediterranean ecosystems from Europe (Arnan et al. 2007; Fernández García et al. 2020), Australia (Lamont and Markey 1995; Clarke et al. 2005; Pausas and Bradstock 2006), California (Keeley et al. 2016) and Cape region from South Africa (Ojeda 1998), this result can be attributed to differences in environmental conditions such as climate and soil fertility.

\section{Soil-vegetation relationships in Mediterranean forests after fire}

The correlation analysis between soil and vegetation at the community level showed several common patterns among study sites: (i) higher AP in terms of stoichiometry (i.e. low C:P and N:P ratios, which are indicators of high mobilization and low $\mathrm{P}$ limitation respectively, Bui and Henderson 2013) was positively related to vegetation growth (annual increases), and additionally, AP decreases with time were higher in the areas with more vegetation. This reflects a feedback loop between AP and vegetation growth, vegetation assimilating orthophosphate for growth, which consequently decreases its soil concentration (Ruttenberg 2005). This fact is widely recognized worldwide, but could be highly relevant in Mediterranean-type climate ecosystems, where phosphorus is often the limiting nutrient (Specht 1969; McLaughlin 1996; Sardans et al. 2005; Sardans and Peñuelas 2007; Orians and Millewski 2007), and fast post-fire regeneration demands substantial amounts of orthophosphate (Ruttenberg 2005; Sardans et al. 2005). (ii) Urease, phosphatase and $\mathrm{MBC}$ were inversely related 


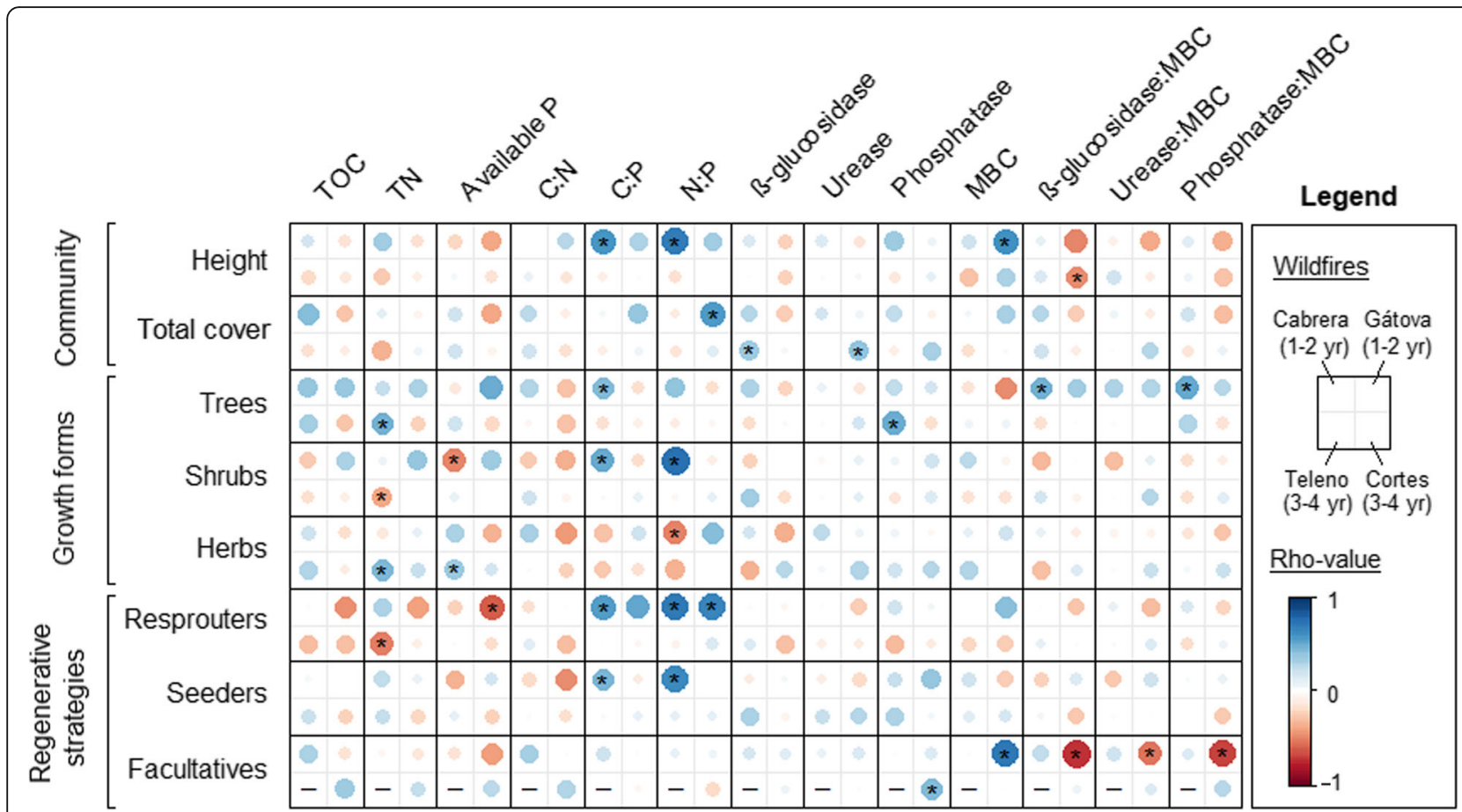

Fig. 6 Relationships between the annual percentage change in soil variables during the 2 years of field sampling ( 1 and 2 years after fire in Cabrera and Gátova, 3 and 4 years after fire in Teleno and Cortes) and the absolute values of vegetation variables during the first sampling year (1 year after fire in Cabrera and Gátova; 3 years after fire in Teleno and Cortes). Height was measured in $\mathrm{cm}$ as the mean maximum height per $\mathrm{m}^{2}$, total cover and the cover by growth forms and regenerative strategies were calculated as the mean percentage cover. Circle sizes are proportional to the absolute value of Spearman's correlation coefficient (Rho-value). * indicates significant correlation $(p<0.05)$. A hyphen indicates that data are not available

to vegetation growth (annual increases), mainly over the very short term after fire (1-2 years). Enzyme activities can be inversely related to vegetation growth because they are scarce in fertile soils (Bünemann 2008). In fact, microorganisms and plants produce extracellular enzymes to catalyze the release of nutrients (ammonia in the case of urease, and phosphate in the case of phosphatase) when there is a deficit (Sollins et al. 1996; Tabatabai 1994; Miesel et al. 2011; Fernández-García et al. 2019b). On the contrary, MBC and vegetation cover are, in general, positively related (Goberna et al. 2007; Ravindran and Yang 2015), because vegetation originates litter, produces root exudates, and better microclimatic conditions for microorganisms, which contribute to nutrient supply source due to fast turnover (Rutigliano et al. 2004; Fernández-García et al. 2020). (iii) The specific activity of soil enzymes (enzyme activity to MBC ratios) was positively related to vegetation cover and height. This result could indicate a higher physiological capacity of the microbial community in soils with high vegetation cover (Waldrop et al. 2000; Rutigliano et al. 2004; Fernández-García et al. 2019a). However, this correlation may also indicate a higher proportion of enzymes secreted by roots instead of microorganisms in densely vegetated areas.
Differentiating vegetation by growth forms, we found consistent soil-vegetation relationships across the different study sites for trees, but not for shrubs and herbaceous vegetation. In this sense, our study indicates that AP (in terms of concentration and stoichiometry) is positively related to the growth of trees (annual change in cover), a fact that has been documented worldwide (e.g. McLaughlin 1996; Gradowski and Thomas 2006; Baribault et al. 2012). As the concentration of extractable $\mathrm{P}$ in soil depends on the balance between nutrient uptake by plants and organic $\mathrm{P}$ mineralization (McLaughlin 1996; Gallardo 2003; Ruttenberg 2005), we can attribute our results to: (i) The necessity of high AP concentrations for trees to grow, although in general, nutrient uptakes and accumulation capacities are higher in early successional species such as herbs (Sardans and Peñuelas 2013); (ii) The higher organic P mineralization rates in areas covered by trees. In this sense, Gallardo (2003) attributed the higher AP to the role of tree roots and mycorrhizas in mineralizing $\mathrm{P}$, not only via phosphatase activity but also to $\mathrm{P}$ dissolution by oxalates.

We noted differences in soil-vegetation relationships depending on regenerative strategies. In fact, we found that the annual changes in soil properties were more related to resprouters than to seeders, 
whereas the growth of seeders was more related to soil properties than the growth of resprouters. In this sense, Sardans and Peñuelas (2013) indicate that resprouters are more competitive than seeders in nutrient uptake the first years after fire, thus, potentially influencing soils to a greater extent. Other authors also attributed the higher impact of resprouters on soils to the persistence of their radicular system after fire (López-Poma and Bautista 2014; Mayor et al. 2016) and to their higher percentage of belowground biomass (Knox and Clarke 2005). In contrast, the recovery of seeders is highly dependent on environmental conditions, including soil properties and climate (Calvo et al. 2002), as seedlings do not have enough reserves to fund a vigorous regeneration, and they have to develop a new radicular system (Pausas and Keeley 2014).

Focusing on the time after fire, we found that soilvegetation relationships were more significant over the very short term (1-2 years) than over the short term (3-4 years). Additionally, we found that some correlations even changed sign depending on the time after fire (e.g. the absolute value of C:P, N:P and soil biochemical properties with the cover of trees; and the absolute values of enzymatic activities and $\mathrm{MBC}$ with the annual growth of shrubs). Both results indicate that the nature of soil-vegetation relationships may change over time as fire effects on soil and vegetation are less pronounced. This assumption is supported by the fact that fire impacts on soil and vegetation reported in the literature (Certini 2005; Caon et al. 2014; Fernández-García et al. 2019a; Fernández García et al. 2020) led to the relationships found in this study over the very short term. Specifically, it has been demonstrated that in severely burned areas there is a large decrease in enzymatic activities and MBC (Vega et al. 2013; Pourreza et al. 2014; Knelman et al. 2015; FernándezGarcía et al. 2019a), in general, shrubs regenerating better than trees (Fernández-García et al. 2019c; Fernández García et al. 2020). However, many studies indicate that fire impact on soil and vegetation diminishes with time (Calvo et al. 2002; Granged et al. 2011), causing direct soil-vegetation interactions to become more relevant with time. In this sense, previous research in Mediterranean ecosystems indicates that the fire impacts on soil AP, enzymatic activities and $\mathrm{MBC}$ are insignificant or highly softened 5-6 years after fire (Muñoz-Rojas et al. 2016; Hinojosa et al. 2019), and differences in vegetation recovery caused by fire are also attenuated over the short term (Calvo et al. 2002, 2005) suggesting that correlations between soil and vegetation variables during the first years after fire might be mediated by fire impacts rather than by interactions between both compartments.

\section{Potential influence of fire regime variables and environmental conditions}

Previous work has reported that the post-fire status and dynamics of both, soil and vegetation can be affected by fire regime variables such as fire frequency and burn severity (Boerner and Brinkman 2006; Pellegrini et al. 2018; Fernández-García et al. 2019a; Fernández García et al. 2020). In general, frequent fires lead to decreases in organic $\mathrm{C}$ and soil fertility in Mediterranean-type ecosystems (Eugenio et al. 2006; Bui and Henderson 2013; Hinojosa et al. 2020), and may cause increases in soil enzymatic activities and microbial biomass (Fernández-García et al. 2020), Likewise, frequent fires can modify the structure and composition of vegetation, usually fostering transition from forests to shrublands (Caon et al. 2014; Fernández García et al. 2020). In this sense, fire frequency in our study sites ranges from 0.14 to 0.16 fires per decade, a fact that should be considered when extrapolating our results to other situations. In addition, changes caused by fire in soil and vegetation are proportional to burn severity (Goforth et al. 2005; Cerda and Robichaud 2009; Vega et al. 2013), which is also related to post-fire recovery rates (Keeley 2009). Thus, some of the relationships between soil and vegetation in our study sites, where burn severity was, in general, high $(\mathrm{dNBR}>400)$, could be a consequence of the indirect effect of fire impacts rather than of an interaction between both compartments. This fact helps to explain the absence of a positive feedback between soil properties and vegetation cover, which is typical in undisturbed Mediterranean ecosystems and drives vegetation succession (Sardans and Peñuelas 2013; LópezPoma and Bautista 2014).

A significant influence of environmental conditions such as climate and lithology on soil and vegetation as well as on their relationships after fire, is also expected. Our results show consistent patterns in relation to these factors for (i) urease and phosphatase activities, which were higher in the north-western sites, because they can be stimulated under wetter conditions (Zuccarini et al. 2020). Acid-phosphatase activity can also be higher in siliceous soils (north-western) than in calcareous soils (eastern) (Tabatabai 1994). (ii) The higher cover of resprouters than seeders in the north-western sites, and vice versa. This coincides with the theoretical model supported by Clarke et al. (2005) and Pausas and Keeley (2014), in which seeding is advantageous over resprouting under aridity conditions, because of the existence of gaps and the ability of seeds to delay germination until conditions are optimal. (iii) The inverse relationship of shrubs and resprouters with the available $\mathrm{P}$ concentration and stoichiometry in the north-western sites, which 
could be explained by differences in climate, but also by the low nutritional demands of the shrub species that dominate in Cabrera and Teleno acidic soils (Erica australis, Pterospartum tridentatum and Halimium lasianthum) (Turrión et al. 2007). In view of the foregoing, we encourage future research to further disentangle the influence of fire regime variables, climate conditions and soil type on soil-vegetation relationships in Mediterranean post-fire environments.

\section{Conclusions}

In this work we have provided pioneer insights into relationships between soil and vegetation status and dynamics after four large wildfires. Thus, we have accomplished an extensive analysis to show soilvegetation relationships at different times after wildfires, in ecosystems with contrasting environmental conditions, and differentiating vegetation growth forms and regenerative strategies.

Among the contributions of the present work, we would like to highlight the following: (i) the study site conditions play an important role in mediating soilvegetation relationships; (ii) available $\mathrm{P}$ content and stoichiometry (C:P and N:P) are closely related to vegetation growth, and particularly to the growth of trees; (iii) enzymatic activities and microbial biomass are inversely related to vegetation growth rates; (iv) the specific activity of soil enzymes is higher in areas with higher vegetation height and cover; (v) annual changes in soil properties were more related to resprouters than to seeders, whereas the growth of seeders was more related to soil status than the growth of resprouters; (vi) the nature of soil-vegetation relationships may change over time as fire effects are less dominant in both ecosystem compartments.

This study constitutes a benchmark in the analysis of soil-vegetation interactions, and contributes to advancing knowledge of the post-fire dynamics of Mediterranean forest ecosystems. Likewise, we encourage future research to specifically elucidate the importance of factors that can influence soil-vegetation relationships after fire, such as fire frequency, burn severity or post-fire meteorological conditions.

\section{Supplementary Information}

The online version contains supplementary material available at https://doi. org/10.1186/s40663-021-00295-y.

\section{Additional file 1.}

\section{Abbreviations}

TOC: Total organic carbon; TN: Total nitrogen; AP: Available phosphorus; C:N: Total organic carbon to total nitrogen ratio; C:P: Total organic carbon to available phosphorus ratio; N:P: Total nitrogen to available phosphorus ratio; MBC: Microbial biomass carbon

\section{Acknowledgements}

Not applicable.

\section{Authors' contributions}

V.F.-G., E.M. and L.C. conceived and designed the experiment; V.F.-G. and S.H. analyzed the soils; V.F.-G., E.M., S.H. and L.C. obtained the data of the vegetation in the field; V.F.-G. analyzed the data; V.F.-G. wrote the first draft of the paper and E.M., S.H. and L.C. contributed to the writing; L.C. coordinated the study. The author(s) read and approved the final manuscript.

\section{Funding}

This study was supported by the Spanish Ministry of Economy and Competitiveness, and the European Regional Development Fund (ERDF), in the framework of the GESFIRE (AGL2013-48189-C2-1-R) and FIRESEVES (AGL2017-86075-C2-1-R) projects; and by the Regional Government of Castile and León in the framework of the FIRECYL (LE033U14) and SEFIRECYL (LE001P17) projects (funding for data collection and soil analyses). SH was supported by a predoctoral fellowship (EDU/574/2018) from the Regional Government of Castile and León and the European Social Fund.

\section{Availability of data and materials}

The datasets generated during the current study are available from the corresponding author on reasonable request.

Ethics approval and consent to participate

Not applicable.

\section{Consent for publication}

Not applicable.

\section{Competing interests}

The authors declare that they have no competing interests.

Received: 29 September 2020 Accepted: 17 February 2021

Published online: 01 March 2021

\section{References}

AEMET-IM (2011) Iberian climate atlas. Air temperature and precipitation (19712000). Agencia Estatal de Meteorología, Ministerio de Medio Ambiente y Medio Rural y Marino and Instituto de Meteorologia de Portugal. https:// www.aemet.es/documentos/es/conocermas/publicaciones/Atlas-clima tologico/Atlas.pdf

Alcañiz M, Outeiro L, Francos M, Farguell J, Úbeda X (2016) Long-term dynamics of soil chemical properties after a prescribed fire in a Mediterranean forest (Montgrí massif, Catalonia, Spain). Sci Total Environ. https://doi.org/10.1016/j. scitotenv.2016.01.115

Aponte C, García LV, Pérez-Ramos IM, Gutiérrez E, Marañon T (2011) Oak trees and soil interactions in Mediterranean forests: a positive feedback model. J Veg Sci. https://doi.org/10.1111/j.1654-1103.2011.01298.x

Aponte C, Marañón T, García LV (2010) Microbial C, N and P in soils of Mediterranean oak forests: influence of season, canopy cover and soil depth. Biogeochemistry. https://doi.org/10.1007/s10533-010-9418-5

Arnan X, Rodrigo A, Retana J (2007) Vegetation type and dryness drive the postfire regeneration of Mediterranean plant communities at a regional scale. J Veg Sci. https://doi.org/10.1658/1100-9233(2007)18[111:PROMPC]2.0.CO;2

Baribault TW, Kobe RK, Finley AO (2012) Tropical tree growth is correlated with soil phosphorus, potassium, and calcium, though not for legumes. Ecol Monogr. https://doi.org/10.1890/11-1013.1

Blair DP, McBurney LM, Blanchard W, Banks SC, Lindenmayer DB (2016) Disturbance gradient shows logging affects plant functional groups more than fire. Ecol Appl. https://doi.org/10.1002/eap.1369

Boerner REJ, Brinkman JA (2006) Fire frequency and soil enzyme activity in southern Ohio oak-hickory forests. Appl Soil Ecol. https://doi.org/10.1016/ S0929-1393(03)00022-2

Bremner JM, Mulvaney CS (1982) Nitrogen total. In: Page AL, Miller RH, Keeney DR (eds) Methods of soil analysis. Part 2: chemical and microbiological properties, 2nd edition. ASA, Madison, Wisconsin, USA, pp 595-624

Bui EN, Henderson BR (2013) C:N:P stoichiometry in Australian soils with respect to vegetation and environmental factors. Plant Soil. https://doi.org/10.1007/ s11104-013-1823-9 
Bünemann EK (2008) Enzyme additions as tool to assess the potential bioavailability of organically bound nutrients. Soil Biol Biochem. https://doi. org/10.1016/j.soilbio.2008.03.001

Calvo L, Santalla S, Marcos E, Valbuena L, Tárrega R, Luis E (2003) Regeneration after wildfire in communities dominated by Pinus pinaster, an obligate seeder, and in others dominated by Quercus pyrenaica, a typical resprouter For Ecol Manag. https://doi.org/10.1016/S0378-1127(03)00207-X

Calvo L, Tárrega R, de Luis E (2002) Secondary succession after perturbations in a shrubland community. Acta Oecol. https://doi.org/10.1016/S1146-609X(02 )01164-5

Calvo L, Tárrega R, Luis E, Valbuena L, Marcos E (2005) Recovery after experimental cutting and burning in three shrub communities with different dominant species. Plant Ecol. https://doi.org/10.1007/s11258-005-0200-z

Caon L, Vallejo VR, Ritsema CJ, Geissen V (2014) Effects of wildfire on soil nutrients in Mediterranean ecosystems. Earth-Sci Rev. https://doi.org/10.1016/ j.earscirev.2014.09.001

Capitanio R, Carcaillet C (2008) Post-fire Mediterranean vegetation dynamics and diversity: a discussion of succession models. For Ecol Manag. https://doi. org/10.1016/j.foreco.2007.09.010

Cerda A, Robichaud P (2009) Fire effects on soils and restoration strategies. CRC Press, Boca Raton, Florida, USA

Certini G (2005) Effects of fire on properties of forest soils: a review. Oecologia. https://doi.org/10.1007/s00442-004-1788-8

Clarke PJ, Knox KJE, Wills K, Campbell M (2005) Landscape patterns of woody plant response to crown fire: disturbance and productivity influence sprouting ability. J Ecol. https://doi.org/10.1111/j.1365-2745.2005.00971.x

De Luis M, Raventós J, González-Hidalgo JC (2006) Post-fire vegetation succession in Mediterranean gorse shrublands. Acta Oecol. https://doi.org/10.1016/j.acta 0.2006 .01 .005

Dumas JBA (1831) Procedes de l'analyse organic. Annales de chimie et de physique 247:198-213

Dupuy J, Fargeon H, Martin-StPaul N, Pimont F, Ruffault J, Guijarro M, Hernando C, Madrigal J, Fernandes P (2020) Climate change impact on future wildfire danger and activity in southern Europe: a review. Ann For Sci. https://doi. org/10.1007/s13595-020-00933-5

Eugenio M, Verkaik I, Lloret F, Espelta JM (2006) Recruitment and growth decline in Pinus halepensis populations after recurrent wildfires in Catalonia (NE Iberian Peninsula). For Ecol Manag. https://doi.org/10.1016/j.foreco.2006.05. 007

Fernández García V, Marcos E, Reyes O, Calvo L (2020) Do fire regime attributes affect soil biochemical properties in the same way under different environmental conditions? Forests. https://doi.org/10.3390/f11030274

Fernández-García V, Fulé PZ, Marcos E, Calvo L (2019c) The role of fire frequency and severity on the regeneration of Mediterranean serotinous pines under different environmental conditions. For Ecol Manag. https://doi.org/10.1016/j. foreco.2019.04.040

Fernández-García V, Marcos E, Fernández-Guisuraga JM, Taboada A, SuárezSeoane S, Calvo L (2019a) Impact of burn severity on soil properties in a Pinus pinaster ecosystem immediately after fire. Int J Wildland Fire. https:// doi.org/10.1071/WF18103

Fernández-García V, Marcos E, Fulé PZ, Reyes O, Santana V, Calvo L (2020) Fire regimes shape diversity and traits of vegetation under different climatic conditions. Sci Total Environ. https://doi.org/10.1016/j.scitotenv.2020.137137

Fernández-García V, Miesel J, Baeza MJ, Marcos E, Calvo L (2019b) Wildfire effects on soil properties in fire-prone pine ecosystems: indicators of burn severity legacy over the medium term after fire. Appl Soil Ecol. https://doi.org/10.101 6/j.apsoil.2018.12.002

Fernández-García V, Santamarta M, Fernández-Manso A, Quintano C, Marcos E, Calvo $L$ (2018) Burn severity metrics in fire-prone pine ecosystems along a climatic gradient using Landsat imagery. Remote Sens Environ. https://doi. org/10.1016/j.rse.2017.12.029

Gallardo A (2003) Effect of tree canopy on the spatial distribution of soil nutrients in a Mediterranean Dehesa. Pedobiologia. https://doi.org/10.1078/0031-405600175

GEODE (2020) Mapa continuo digital de España. Instituto Geológico y Minero de España. http://mapas.igme.es/gis/services/Cartografia_Geologica/IGME_ Geode_50/MapServer/WMSServer. Accessed 29 Aug 2020

Goberna M, Pascual JA, García C, Sánchez J (2007) Do plant clumps constitute microbial hotspots in semiarid Mediterranean patchy landscapes? Soil Biol Biochem. https://doi.org/10.1016/j.soilbio.2006.11.015
Goforth BR, Graham RC, Hubbert KR, Zanner CW, Minnich RA (2005) Spatial distribution and properties of ash and thermally altered soils after highseverity forest fire, southern California. Int J Wildland Fire. https://doi.org/10.1 071/WF05038

Gradowski T, Thomas SC (2006) Phosphorus limitation of sugar maple growth in Central Ontario. For Ecol Manag. https://doi.org/10.1016/j.foreco.2005.12.062

Granged A, Zavala LM, Jordán A, Bárcenas-Moreno G (2011) Post-fire evolution of soil properties and vegetation cover in a Mediterranean heathland after experimental burning: a 3-year study. Geoderma. https://doi.org/10.1016/j. geoderma.2011.05.017

Harrell FE (2020) Hmisc: Harrell miscellaneous. R package version 4, p 4 https:// CRAN.R-project.org/package=Hmisc. Accessed 29 Aug 2020

Hinojosa MB, Albert-Belda E, Gómez-Muñoz B, Moreno JM (2020) High fire frequency reduces soil fertility underneath woody plant canopies of Mediterranean ecosystems. Sci Total Environ. https://doi.org/10.1016/j. scitotenv.2020.141877

Hinojosa MB, Laudicina VA, Parra A, Albert-Belda E, Moreno JM (2019) Drought and its legacy modulate the post-fire recovery of soil functionality and microbial community structure in a Mediterranean shrubland. Glob Change Biol. https://doi.org/10.1111/gcb.14575

Hinojosa MB, Parra A, Laudicina VA, Moreno JM (2016) Post-fire soil functionality and microbial community structure in a Mediterranean shrubland subjected to experimental drought. Sci Total Environ. https://doi.org/10.1016/j. scitotenv.2016.03.117

Joergensen JG (1996) The fumigation-extraction method to estimate soil microbial biomass: calibration of the kEC value. Soil Biol Biochem. https://doi. org/10.1016/0038-0717(95)00102-6

Kandeler E, Gerber H (1988) Short-term assay of soil urease activity using colorimetric determination of ammonium. Biol Fertil Soils. https://doi.org/10.1 007/BF00257924

Keeley JE (2009) Fire intensity, fire severity and burn severity: A brief review and suggested usage. Int J Wildland Fire. https://doi.org/10.1071/WF07049

Keeley JE, Pausas JE, Rundel PW, Bond WJ, Bradstock RA (2011) Fire as an evolutionary pressure shaping plant traits. Trends Plant Sci. https://doi.org/1 0.1016/j.tplants.2011.04.002

Keeley JE, Thomas Parker V, Vasey MC (2016) Resprouting and seeding hypotheses: a test of the gap-dependent model using resprouting and obligate seeding subspecies of Arctostaphylos. Plant Ecol. https://doi.org/10.1 007/s11258-015-0551-z

Keesstra S, Wittenberg L, Maroulis J, Sambalino F, Malkinson D, Cerdà A, Pereira P (2017) The influence of fire history, plant species and post-fire management on soil water repellency in a Mediterranean catchment: the Mount Carmel range, Israel. Catena. https://doi.org/10.1016/j.catena.2016.04.006

Key CH, Benson NC (2006) Landscape assessment (LA) sampling and analysis methods; general technical report, RMRS-GTR-164-CD; U.S. Department of Agriculture, Forest Service, Rocky Mountain Research Station: Fort Collins, CO, USA.

Knelman JE, Grahan EB, Trahan NA, Schmidt SK, Nemergut DR (2015) Fire severity shapes plant colonization effects on bacterial community structure, microbial biomass, and soil enzyme activity in secondary succession of a burned forest. Soil Biol Biochem. https://doi.org/10.1016/j.soilbio.2015.08.004

Knox KJE, Clarke PJ (2005) Nutrient availability induces contrasting allocation and starch formation in resprouting and obligate seeding shrubs. Funct Ecol. https://doi.org/10.1111/j.1365-2435.2005.01006.x

Kutiel P, Naveh Z (1987) Soil properties beneath Pinus halepensis and Quercus calliprinos trees on burned and unburned mixed forest on Mt. Carmel, Israel. For Ecol Manag. https://doi.org/10.1016/0378-1127(87)90147-2

Lamont BB, Markey A (1995) Biogeography of firekilled and resprouting Banksia species in South-Western Australia. Aust J Bot. https://doi.org/10.1071/ BT9950283

López-Poma R, Bautista S (2014) Plant regeneration functional groups modulate the response to fire of soil enzyme activities in a Mediterranean shrubland. Soil Biol Biochem. https://doi.org/10.1016/j.soilbio.2014.08.016

Mayor AG, Goirán SB, Vallejo VR, Bautista S (2016) Variation in soil enzyme activity as a function of vegetation amount, type, and spatial structure in fire-prone Mediterranean shrublands. Sci Total Environ. https://doi.org/10.1016/j. scitotenv.2016.03.139

McLaughlin MJ (1996) Phosphorus in Australian forest soils. In: Attiwill PM, Adams MA (eds) Nutrition in eucalypts. CSIRO, Melbourne, Australia, pp 1-30

Miesel JR, Boerner RE, Skinner CN (2011) Soil nitrogen mineralization and enzymatic activities in fire and fire surrogate treatments in California. Can J Soil Sci. https://doi.org/10.4141/CJSS10098 
Montès N, Ballini C, Bonin G, Faures J (2004) A comparative study of aboveground biomass of three Mediterranean species in a post-fire succession. Acta Oecol. https://doi.org/10.1016/j.actao.2003.10.002

Moreira F, Ascoli D, Safford H, Adams MA, Moreno JM, Pereira JM, Catry FX, Armesto J, Bond W, González ME, Curt T, Koutsias N, McCaw L, Price O, Pausas JG, Rigolot E, Stephens S, Tavsanoglu C, Vallejo VR, Van Wilgen BW, Xanthopoulos G, Fernandes PM (2020) Wildfire management in Mediterranean-type regions: paradigm change needed. Environ Res Lett. https://doi.org/10.1088/1748-9326/ab541e

Moya D, González-De Vega S, García-Orenes F, Morugán-Coronado A, Arcenegui V, Mataix-Solera J, Lucas-Borja ME, de las Heras J (2018) Temporal characterisation of soil-plant natural recovery related to fire severity in burned Pinus halepensis mill. forests. Sci Total Environ. https://doi.org/10.101 6/j.scitotenv.2018.05.212

Muñoz-Rojas M, Erickson TE, Martini D, Dixon KW, Merritt D (2016) Soil physicochemical and microbiological indicators of short, medium and long term post-fire recovery in semi-arid ecosystems. Ecol Indic. https://doi.org/1 0.1016/j.ecolind.2015.11.038

Nelson DW, Sommers LE (1982) Total carbon, organic carbon and organic matter. In: Page AL, Miller RH, Keeney DR (eds) Methods of soil analysis, part 2. Chemical and Microbiological Properties. ASA, Madison, Wisconsin, USA, pp 539-579

Ninyerola M, Pons X, Roure JM (2005) Atlas Climático digital de la Península Ibérica. Metodología y aplicaciones en bioclimatología y geobotánica. Universidad Autónoma de Barcelona, Spain http://opengis.uab.es/wms/iberia. Accessed 29 Aug 2020

Ojeda F (1998) Biogeography of seeder and resprouter Erica species in the cape floristic region-where are the resprouters? Biol J Linn Soc. https://doi.org/1 0.1111/j.1095-8312.1998.tb01521.x

Ojeda F, Brun FG, Vergara JJ (2005) Fire, rain and the selection of seeder and resprouter life-histories in fire-recruiting, woody plants. New Phytol. https:// doi.org/10.1111/j.1469-8137.2005.01486.x

Olsen SR, Cole CV, Frank SW, Dean LA (1954) Estimation of available phosphorus in soils by extraction with sodium bicarbonate. USDA circular no. 939. US government printing office, Washington DC. USA

Orians GH, Millewski AV (2007) Ecology of Australia: the effects of nutrient-poor soils and intense fires. Biol Rev. https:/doi.org/10.1111/j.1469-185X.2007.00017.x

Pausas JG, Bradstock RA (2006) Fire persistence traits of plants along a productivity and disturbance gradient in Mediterranean shrublands of southEast Australia. Glob Ecol Biogeogr. https://doi.org/10.1111/j.1466-8238.2006. 00283.x

Pausas JG, Keeley JE (2014) Evolutionary ecology of resprouting and seeding in fire-prone ecosystems. New Phytol. https://doi.org/10.1111/nph.12921

Pellegrini A, Ahlström A, Hobbie S, Reich PB, Nieradzik LP, Staver AC, Scharenbroch BC, Jumpponen A, Anderegg WRL, Randerson JT, Jackson RB (2018) Fire frequency drives decadal changes in soil carbon and nitrogen and ecosystem productivity. Nature. https://doi.org/10.1038/nature24668

Pereira P, Cerda A, Martin D, Úbeda D, Depellegrin D, Novara A, Martínez-Murillo JF, Brevik EC, Menshov O, Comino JR, Miesel J (2017) Short-term low-severity spring grassland fire impacts on soil extractable elements and soil ratios in Lithuania. Sci Total Environ. https://doi.org/10.1016/j.scitotenv.2016.10.210

Pereira P, Úbeda X, Martin D (2012) Fire severity effects on ash chemical composition and water-extractable elements. Geoderma. https://doi.org/10.1 016/j.geoderma.2012.02.005

Pourreza M, Hosseini SM, Sinegani AAS, Matinizadeh M, Dick WA (2014) Soil microbial activity in response to fire severity in Zagros oak (Quercus brantii Lindl.) forests, Iran, after one year. Geoderma. https://doi.org/10.1016/j. geoderma.2013.07.024

Quigley KM, Kolka R, Sturtevant BR, Dickinson MB, Kem CC, Donner DM, Miesel JR (2020) Prescribed burn frequency, vegetation cover, and management legacies influence soil fertility: implications for restoration of imperiled pine barrens habitat. For Ecol Manag. https://doi.org/10.1016/j.foreco.2020.118163

R Core Team (2020) R: a language and environment for statistical computing. $R$ Foundation for Statistical Computing, Vienna, Austria https://www.R-project. org/. Accessed 29 Aug 2020

Ravindran A, Yang S (2015) Effects of vegetation type on microbial biomass carbon and nitrogen in subalpine mountain forest soils. J Microbiol Immunol. https://doi.org/10.1016/j.jmii.2014.02.003

Rutigliano FA, D'Ascoli R, De Santo AV (2004) Soil microbial metabolism and nutrient status in a Mediterranean area as affected by plant cover. Soil Biol Biochem. https://doi.org/10.1016/j.soilbio.2004.04.029
Ruttenberg KC (2005) The global phosphorus cycle. In: Holland HD, Turekian KK (eds) Biogeochemistry. Elsevier Science and Technology, Amsterdam, The Netherlands, pp 585-593

Sáenz de Miera LE, Pinto R, Gutierrez-Gonzalez JJ, Calvo L, Ansola G (2020) Wildfire effects on diversity and composition in soil bacterial communities. Sci Total Environ. https://doi.org/10.1016/j.scitotenv.2020.138636

Sardans J, Peñuelas J (2007) Drought changes phosphorus and potassium accumulation patterns in an evergreen Mediterranean forest. Funct Ecol. https://doi.org/10.1111/j.1365-2435.2007.01247.x

Sardans J, Peñuelas J (2013) Plant-soil interactions in Mediterranean forest and shrublands: impacts of climatic change. Plant Soil. https://doi.org/10.1007/ s11104-013-1591-6

Sardans J, Peñuelas J, Rodà F (2005) Changes in nutrient status, retranslocation and use efficiency in young post-fire regeneration Pinus halepensis in response to sudden $\mathrm{N}$ and $\mathrm{P}$ input, irrigation and removal of competing vegetation. Trees. https://doi.org/10.1007/s00468-004-0374-3

Sollins P, Homann P, Caldwell BA (1996) Stabilization and destabilization of soil organic matter: mechanisms and controls. Geoderma. https://doi.org/10.101 6/S0016-7061(96)00036-5

Specht RL (1969) A comparison of the sclerophyllous vegetation characteristic of Mediterranean type climates in France, California, and southern Australia. II. Dry matter, energy, and nutrient accumulation. Aust J Bot 17:293-308

Stevens J, Boisramé GFS, Rakhmatulina E, Thompson SE, Collins BM, Stephens SL (2020) Forest vegetation change and its impacts on soil water following 47 years of managed wildfire. Ecosystems. https://doi.org/10.1007/s10021-02000489-5

Tabatabai MA (1994) Soil enzymes. In: Weaver RW, Angle JS, Bottomley PJ, Bezdicek DF, Smith S, Tabatabai MA, Wollum AG (eds) Methods of soil analysis. Part 2: microbial and biochemical properties. ASA and SSSA, Madison, Wisconsin, USA, pp 775-833

Trabaud L (1991) Le feu Est-il un factor de changement pour les systèmes écologiques du Bassin Méditerranéen? Sécheresse 3:163-174

Turrión MB, López O, Lafuente F, Mulas R, Ruipérez C, Puyo A (2007) Soil phosphorus forms as quality indicators of soils under different vegetation covers. Sci Total Environ. https://doi.org/10.1016/j.scitotenv.2007.01.037

Vance ED, Brookes PC, Jenkinson DS (1987) An extraction method for measuring soil microbial biomass C. Soil Biol Biochem. https://doi.org/10.1016/0038-071 7(87)90052-6

Vega JA, Fontúrbel T, Merino A, Fernández C, Ferreiro A, Jiménez E (2013) Testing the ability of visual indicators of soil burn severity to reflect changes in soil chemical and microbial properties in pine forests and shrubland. Plant Soil. https://doi.org/10.1007/s11104-012-1532-9

Verma S, Singh D, Singh AK, Jayakumar S (2019) Post-fire soil nutrient dynamics in a tropical dry deciduous forest of Western Ghats, India. For Ecosyst. https://doi.org/10.1186/s40663-019-0168-0

Waldrop MP, Balser TC, Firestone MK (2000) Linking microbial community composition to function in a tropical soil. Soil Biol Biochem. https://doi.org/1 0.1016/S0038-0717(00)00157-7

Walkley A, Black IA (1934) An examination of Degtjareff method for determining soil organic matter and a proposed modification of the chromic acid titration method. Soil Sci 37:29-38

Zuccarini P, Asensio D, Ogaya R, Sardans J, Peñuelas J (2020) Effects of seasonal and decadal warming on soil enzymatic activity in a P-deficient Mediterranean shrubland. Glob Chang Biol. https://doi.org/10.1111/gcb.15077

\section{Submit your manuscript to a SpringerOpen ${ }^{\circ}$ journal and benefit from:}

- Convenient online submission

- Rigorous peer review

- Open access: articles freely available online

- High visibility within the field

- Retaining the copyright to your article

Submit your next manuscript at $>$ springeropen.com 